\title{
2. The New Model of Growth and the Global Resources Economy
}

\section{Ross Garnaut ${ }^{1}$}

We said in the introductory chapter to the 2013 China Update book that contemporary changes in economic policy and structure were so comprehensive and profound that they represented a new model of Chinese economic growth (Garnaut et al. 2013a). We called the volume China: A New Model of Growth and Development.

The new model had conventional economic and more subtle institutional dimensions. Cai Fang, Ligang Song and I (Garnaut et al. 2013b) and Huang et al. (2013) explored the former, and Dwight Perkins (2013) explored the institutional changes.

We noted in 2013 that these changes in China would have large international consequences. The changes were particularly important for trade in resourcebased commodities. The old model of growth produced, in the world's most populous country, the strongest, most resource-intensive economic growth the world has ever seen. This gave rise to the extraordinary resources boom of the early twenty-first century. This was of immense importance to development in Australia and many other resource-rich countries.

How is the new model going and how is its progress affecting the global resources economy? This chapter briefly explores the more straightforward economic dimensions of progress so far, and the impact of those changes on some aspects of global resources trade of importance to Australia.

\section{From old to new: The changing character of growth}

The old model of economic development was built on high and rapidly increasing levels of investment, especially in industrial activity and urban infrastructure. It was supported by the movement of huge numbers of workers from the countryside to the towns and cities, allowing strong growth in urban

1 I am grateful for research support from Ligang Song, Ran Li, Derek Cheng and Veronica Webster. 
employment with modest increases in real wages. With wages growing less rapidly than the value of output, the profit share of income rose continually, in turn supporting increases in savings. Much of the massive increase in savings was committed to investment, reinforcing the process of investment-led growth.

Investment-led growth was accompanied by relatively high total factor productivity (TFP) growth, encouraged by deep and deepening integration into the global economy. The internationally oriented growth saw China contributing the majority of the increase in world trade in the early twenty-first century, and a majority of the increase in the surplus of domestic savings over investment that was available for international investment.

Chinese growth in the early twenty-first century was the most rapid over a sustained period in any country since modern economic growth emerged in the United Kingdom a quarter of a millennium ago. It was also the most investment intensive and therefore the most metals intensive and energy intensive the world has ever seen.

The high investment share of expenditure in the reform era was reinforced by the Chinese policy response to massive recessionary shocks from abroad. The first of these was the Asian Financial Crisis of 1997-99 (McLeod and Garnaut 1998). The Chinese Government chose to maintain the exchange value of the renminbi (RMB) against the US dollar despite massive currency depreciation in all of its Western Pacific trading partners. To maintain a reasonable if diminished rate of growth in economic output, employment and incomes through a huge deceleration of export growth and fall in net exports, the authorities engaged in a large Keynesian monetary and fiscal expansion. The second shock was from the global financial crisis (GFC) of 2008. The immediate effects on China were even larger and potentially more destabilising than those of the Asian Financial Crisis. Again, the response was to maintain a fixed exchange rate against the US dollar despite large currency depreciation in other Western Pacific economies, and massive monetary and fiscal expansion to maintain growth in output and employment. Fiscal and monetary expansions were applied on a much larger scale in 2008-09 than during and after the Asian Financial Crisis.

The Keynesian expansions of 1998-99 and 2008-09 were brilliantly successful in supporting the continuation of strong economic growth. They were implemented principally through expansion in the resources made available through stateconnected entities - through local, provincial and national governments as suppliers of infrastructure, and through state-owned enterprises (SOEs), which were disproportionately active in heavy industry - all drawing large amounts of finance from the state-owned banks. 
The outcome was an intensification of the role of investment in the growth process. Investment is much more metals intensive and energy intensive than consumption, so development in the early twenty-first century and especially after the GFC further increased the extraordinary pressure that Chinese growth was placing on world energy and metals markets.

The extraordinary rates, investment intensity, energy intensity and metals intensity of growth in the world's most populous country generated the largest, longest and most broadly based increase in commodity demand that the world economy has ever experienced. Figures 2.1 and 2.2 illustrate how China contributed most of the strong increase in global demand from the beginning of the new century to 2011 for the energy source (thermal coal, Figure 2.1) and metal (steel, Figure 2.2) that were most important in Chinese growth. The central role of China was especially pronounced after the GFC, when growth in demand for energy and metals accelerated in China and decelerated in the rest of the world.

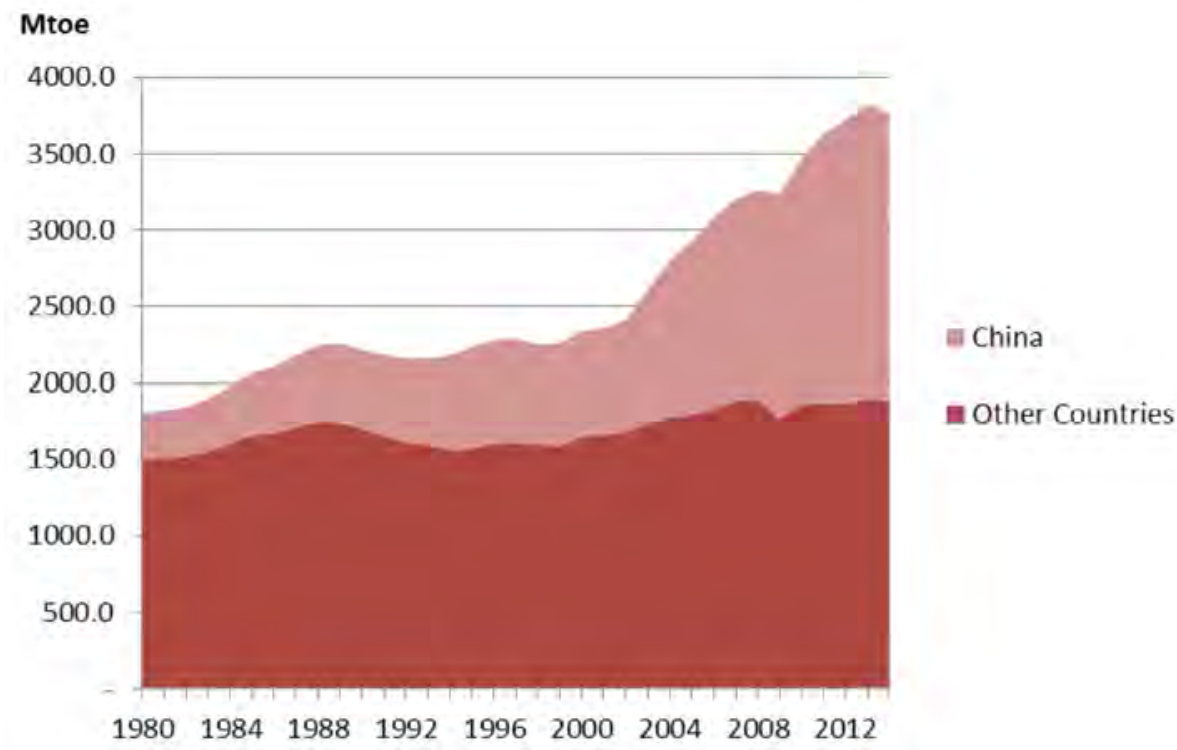

Figure 2.1 Coal consumption of China compared with other countries Source: BP (2015); and author's estimation. 
China's Domestic Transformation in a Global Context

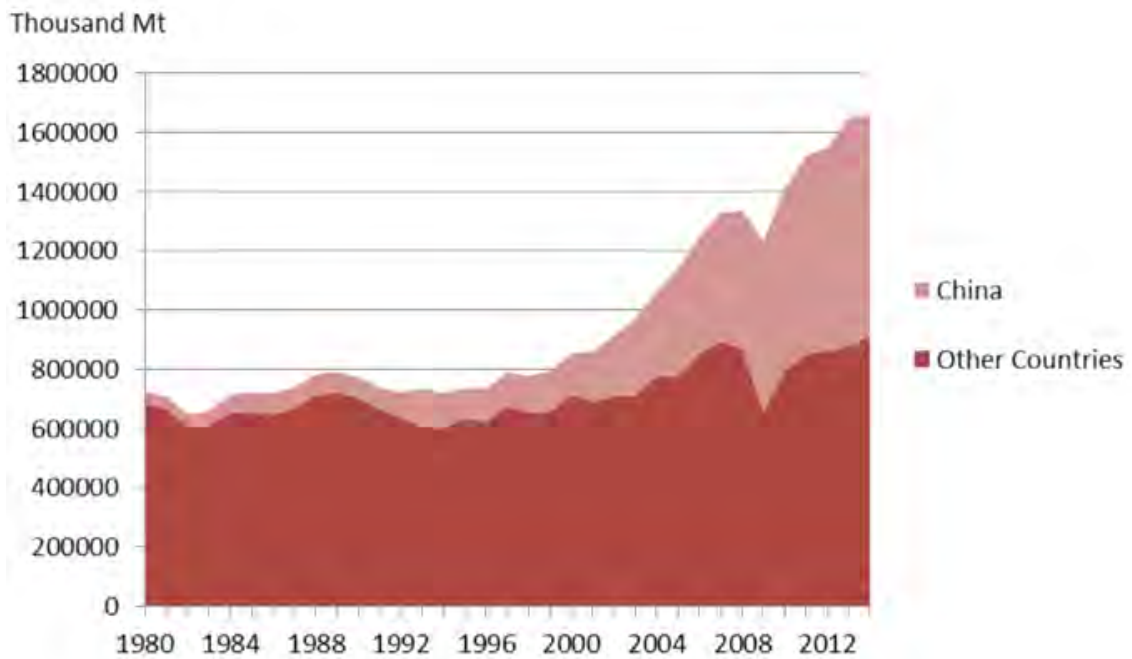

Figure 2.2 Steel consumption of China compared with other countries

Source: World Steel Association (2015); and author's estimation.

The increase in China's demand took suppliers of metals and energy by surprise. Investment in expanding mining capacity lagged a long way behind demand for all metals and major energy sources. Prices rose to or close to their highest levels ever in real terms (see Figures 2.3, 2.4 and 2.5 for thermal coal, oil and copper, respectively).

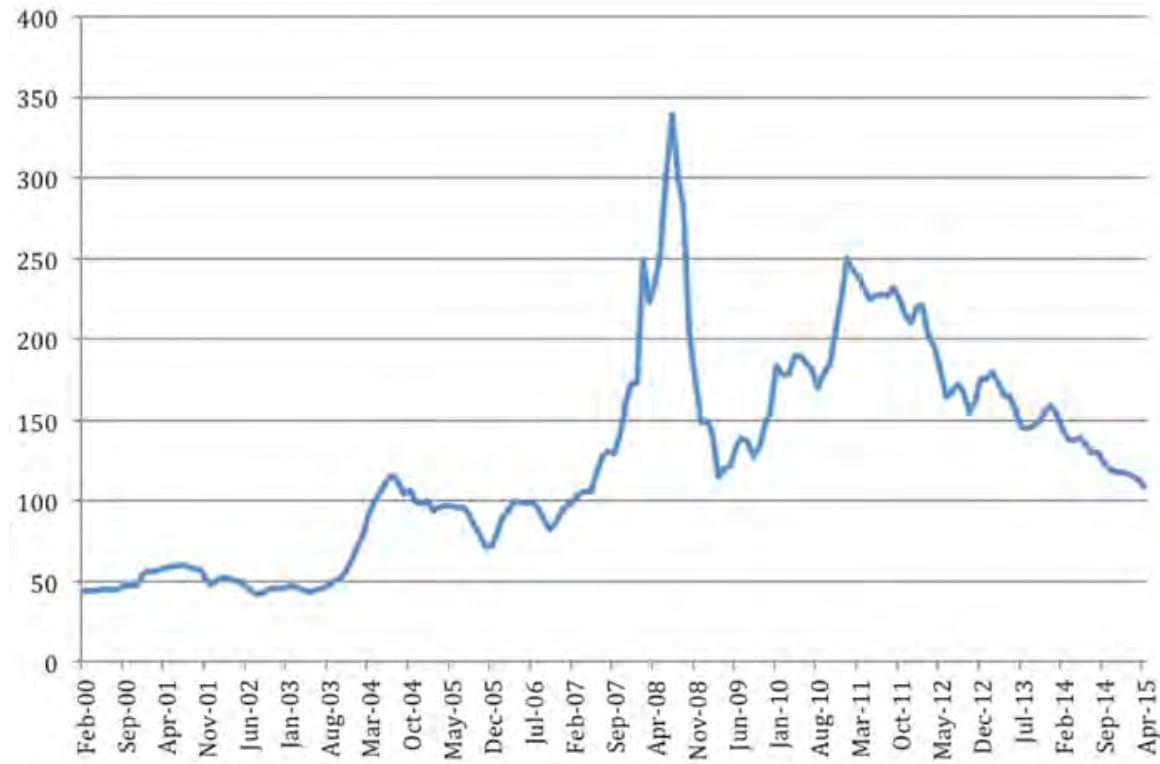

Figure 2.3 Thermal coal price index (US\$/Mt; 2007 prices, 2007=100)

Note: FOB Newcastle/Port Kembla.

Source: Index Mundi (2014). Reproduced from Garnaut (forthcoming 2015). 


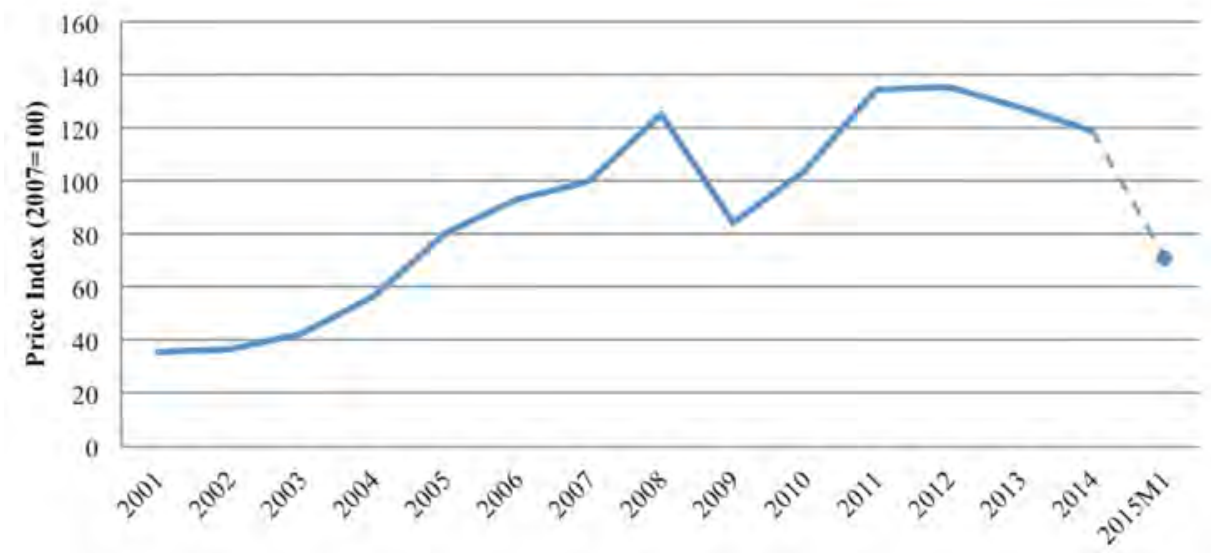

Figure 2.4 Crude oil price index (US\$/bbl; 2007 prices, 2007=100)

Source: Price data from World Bank and EIA; US goods deflator from IMF International Financial Statistics (2007\$). Reproduced from Garnaut (forthcoming 2015).

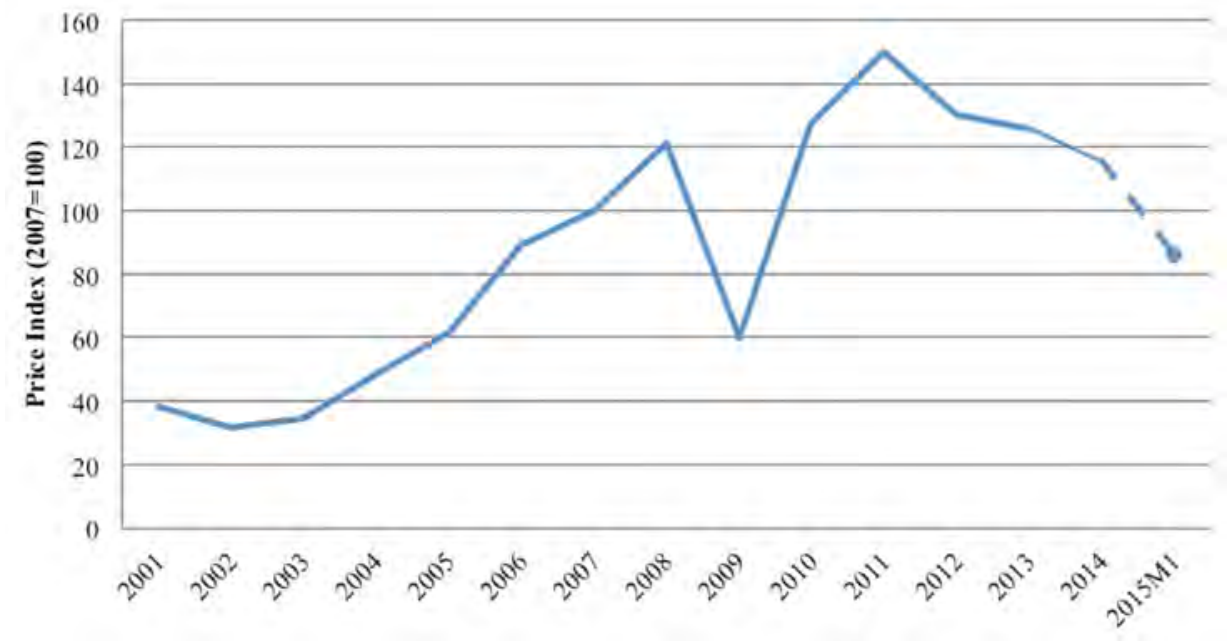

Figure 2.5 Copper price index (US\$/Mt; 2007 prices, 2007=100)

Source: Price data from London Metal Exchange via Datastream; US Goods Deflator from IMF International Financial Statistics (2007\$). Reproduced from Garnaut (forthcoming 2015).

Two separate forces are driving the transition to the new model of economic growth. One is straightforwardly economic: pressures that emerge naturally from successful economic development. The other is the change in national objectives and policy, towards more equitable distribution of income and less damaging impacts on the domestic and international natural environment. The changes in objectives and policy are themselves partly a response to rising incomes, which reduce the priority of higher material living standards relative to other dimensions of the quality of life. 
The economic pressures from successful development come from the raising of the wage at which people are prepared to leave the countryside for work in urban areas (Cai 2010; Garnaut 2010; Garnaut and Song 2006; Huang and Cai 2013; Huang and Jiang 2010). The movement of people from the countryside to urban employment reduces pressures on agricultural resources and raises rural material standards of living. The people who remain in rural villages after the early decades of rapid economic growth tend to have better opportunities at home and require greater inducements to migrate to the towns than those who went before them. To the extent that some of the fruits of economic development are allocated by government as transfers to rural residents and to rural services such as health, education, telecommunications and transport, the urban wage required to induce migration increases. A long history of fertility well below replacement levels eventually causes the number of new entrants into the labour force each year to fall. And the increase in urban demand for labour with sustained rapid growth increases demand for labour at a steady wage (Huang et al. 2013).

Scarcity of low-skilled labour and a tendency for wages to rise more rapidly than the value of output were evident in the major coastal cities from about 2005 and became more widespread with each passing year until the disruption of the GFC. The tendency was broken briefly by the GFC, but returned late in 2009 as the powerful monetary and fiscal expansion became effective. It has continued since then, despite the slowing of economic growth.

These pressures from the labour market began to force profound change in the composition and rate of growth. Sooner or later, they were bound to be associated with a rise in the consumption and fall in the savings and investment shares of national income. The reduction in the investment share of expenditure, in turn, could be expected to reduce the rate of growth of the capital stock and therefore the aggregate rate of growth. The rate of growth of the labour contribution fell to near zero with the stagnation and then decline of the working-age population from about 2012. The decline in the rate of growth in the capital and labour contributions might be expected to reduce over time the overall rate of growth by several percentage points, from about 10 per cent per annum to about 7 per cent, and eventually lower still.

The changes in objectives and policy emerged gradually, but had taken full shape by 2012. Implementation of policy took longer but now has considerable momentum.

The widening of the dispersion of income distribution was a source of comment and growing concern among economists and parts of the population and leadership from the early years of the century. Policies to increase rural incomes and services and to expand consumption especially of services were defined 
and gradually strengthened throughout the $\mathrm{Hu}-$ Wen period of government. They were eclipsed during the slowdown after the GFC, but were back on the agenda by 2010 and were central in the Twelfth Five-Year Plan 2011-15.

The energy-intensive pattern of growth of the early twenty-first century placed immense pressure on the global environment through growing greenhouse gas emissions. It was also causally important in the deterioration of air and water quality to an extent that was seriously damaging to human health and life expectancy. Both global and local environmental costs were especially high because of the exceptionally large role of coal as an energy source in power generation and industry.

China contributed a majority of the global increase in greenhouse gas emissions through the first decade of the century. This attracted increasing disquiet within the Chinese scientific community, which had access to the premier and other leading policymakers. It also attracted critical comment from the governments of developed countries as the international community geared up for stronger action to mitigate human-induced climate change in the lead-up to and after the Copenhagen conference of the United Nations in December 2009. China made commitments on reductions in the emissions intensity of economic activity to the international community at Cancun in 2010 that required a substantial change in the structure of economic growth.

Concern over local environmental effects has risen in a number of steps since the GFC. The focus on dangerously high concentrations of small carbon particulates in the air in cities of eastern and northern China has intensified with scientific study of their effects on health and increasing attention in popular media (Chen et al. 2013). This has been a major focus of popular concern at least since early 2013 (Chai 2015). It has become a separate and powerful driver of policy to diminish the energy intensity of economic activity and the dominant position of coal in energy use.

Official policy continues to elevate the priority of reductions in energy intensity and the substitution of all of the low-emission alternatives for coal.

\section{Smooth and rough adjustment}

The new model of economic growth embodies structural change at an immense scale and pace.

One can define a possible path of smooth adjustment that would see rapid but gradual offsetting changes in the main growth parameters that together ensure the continuation of reasonably strong growth in output, employment and incomes of most people. But one can also identify the possibility of investment 
falling more than consumption is rising and productivity failing to rise to compensate for lower contributions from other sources of growth in output and incomes. The latter possibility would involve disruption of growth in output and incomes. Disruption would introduce risks of financial or political dislocation, compounding the initial loss of growth momentum.

Smooth adjustment would see the maintenance or even some acceleration of TFP growth as the contributions of growth in the capital stock and labour force declined. Rising real wages introduce pressure to raise productivity. There is an opportunity to lift productivity growth to an extent that moderates considerably the decline in the rate of output growth within the new development model. The focus on improvement of the institutions for market regulation and exchange can raise productivity. The focus on increased investment in education within the new model of growth combines with the large decline in the school-age population to introduce prospects for greatly improved labour quality, which shows up as increased TFP. Success in raising productivity growth depends especially on the institutional reforms discussed by Perkins (2013) in his contribution to this series two years ago. It depends on maintenance of openness to the international economy in all of its dimensions. It requires far-reaching financial system reform to allow capital to move quickly and in large quantities to its most productive uses. Strong growth in TFP requires acceptance of rapid changes in the composition of economic activity in line with rapidly changing comparative advantage. It requires improvement of market institutions, including through increased transparency and reliability of state mechanisms for regulating legal relations between the state and private entities and among private businesses. These improvements require strengthening of rights to intellectual and real property. Success in maintaining and lifting productivity growth requires heavy investment in education and training. It requires easy and low-cost transfers of economic information within China and between Chinese and overseas individuals and enterprises.

Adjustment to the new model of growth requires an absolute reduction in total investment and not just a fall in the investment share of expenditure. Changes in the required level of investment - and therefore demand for inputs into investment - depend not on the rate of growth in the economy, but on changes in the rate of growth. Here we have the old-fashioned Keynesian accelerator at work. The rate of growth of output is expected to fall by about one-third within the new model of growth - from about 10 per cent per annum to about 7 per cent (and eventually to lower levels). In the absence of changes in the productivity-related influences that determine the capital-output ratio, the level of investment can be expected to fall by a similar proportion. Consumption has to rise quickly and by a large amount to maintain domestic demand that is consistent with maintenance of the new, lower potential rate of growth. 
Smooth adjustment would see consumption rising as investment falls. Rising consumption shares of a more slowly growing national output and income - reversing many years of falling consumption shares - could see the rate of growth in consumption remaining as strong or stronger than in earlier years under the old growth model. But the absence of timely and large increases in consumption introduces the risk of disturbingly large slumps in the growth of incomes, expenditure and output.

The decline in the share and level of investment has massive effects on the inter-industrial structure of demand. In particular, investment uses metals and energy far more intensively than consumption, so that sharply lower investment means a slump in demand for the products of heavy industry that had central roles in the old model of growth. Coal and steel are the most prominent of the industries subject to lower demand growth - with coal being affected as well by the shift to low-emission sources of power generation that follows the elevation of environmental amenity among national objectives. The slowing rate of urbanisation after the turning period of Chinese economic development induces deceleration in growth in demand for all of the infrastructure required by a growing urban population, including housing and transport infrastructure. As with demand for investment goods, this induces an absolute fall in demand for many goods that occupied a large place within the old model of growth. This is an important part of the current anxiety about oversupply of housing in many Chinese cities - an oversupply that is transmitted with acceleration into supplying industries.

The massive structural adjustment required by the new model of growth compounds risks of disruption that emerged in the mature stage of the old model of growth. The unprecedentedly high investment shares of gross domestic product (GDP) channelled disproportionately through state agencies led to overinvestment in some areas of heavy industry and infrastructure. Provincial and local government sponsorship of real estate developments in particular was associated with strong growth in revenue during the later years of the old model of growth. Financial institutions that had provided funds for infrastructure and heavy industry are vulnerable to the deterioration in the fortunes of these mainstays of the old growth model - as are provincial and local governments, whose revenues came to depend excessively on new urban development during the period of rapid, investment-led growth. The pullback in investment in urban development and heavy industry under the new model has led to severe imbalances in local government finances and vulnerability in the balance sheets of many financial institutions (Wong 2015; Yu 2009). Financial reform is necessary for success in transition to the new model of economic growth, but is inhibited by the fragility of financial institutions deriving from the lending patterns of the era of investment-led growth. 
The materialisation of severe macroeconomic or financial sector imbalances would affect the state's capacity to implement in a timely way policies to secure transition to the new model of growth. The possibility of smooth adjustment is surrounded by risks of a much rougher ride. The large fall in real estate activity and therefore demand for steel and cement in early 2015 contain elements of temporary disruption on top of the tendencies to secular decline.

\section{Changes in growth so far}

These are early years in the change of policy in a great state and the change of the trajectory of economic development in an immense economy-now the world's largest in purchasing power terms. The natural economic pressures driving the new model of growth have been working consistently since the recovery from the GFC in 2010. The policy changes have been applied in more and more areas since 2011. Anticipated changes in economic structure are apparent in the statistical record, but mostly weakly.

Here I focus on the conventional economic dimensions of change. The qualitative, institutional changes required by the new model were emphasised in the elaborate decisions of the Third Plenum of the Eighteenth Central Committee in 2013. They are being taken seriously, without so far being applied consistently and effectively. Institutional change takes time in the best of circumstances and it will be some years before sound judgments can be made about reform achievements in these areas.

The rate of growth has slowed decisively - consistent with the requirements of the new model (Figure 2.6). Recent expressions of goals for the rate of growth by leading members of the government have gathered around 7 per cent with acknowledgement that outcomes may turn out to be weaker. Major easing of monetary policy so far in 2015 is directed at supporting growth near these levels, modest as they are by the standards of the reform era.

Real wages rose well above output growth for the first time in 2009. Since then, wage growth has remained much stronger than output as the latter has eased in recent years.

The standard measure of inequality, the Gini coefficient, rose to a peak in 2008 and has eased steadily, if slowly, since then (Figure 2.7). The change in trajectory of the Gini coefficient reflects the acceleration of increases in wages relative to output as well as the introduction of policies designed to reduce inequality. 


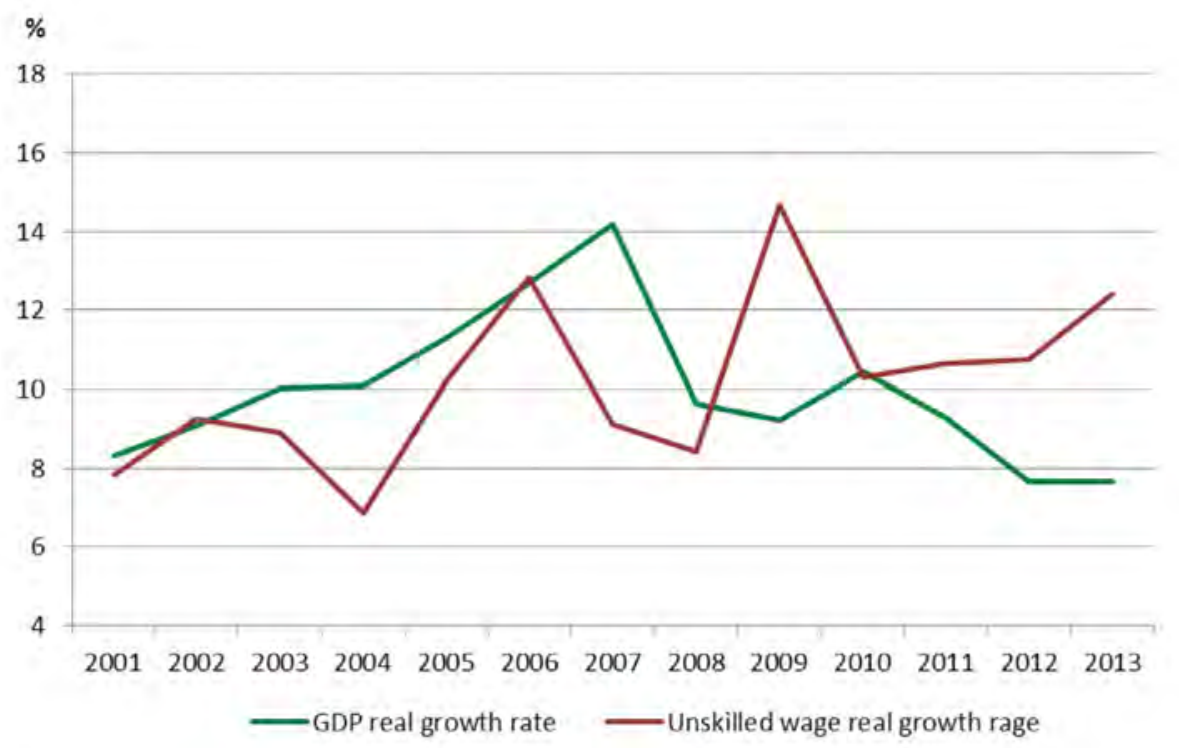

Figure 2.6 Real growth rate of GDP and wage of low-skilled workers

Note: Average wage in the construction industry is used as a proxy for that in low-skilled industries. Sources: IMF-IFS; National Bureau of Statistics.

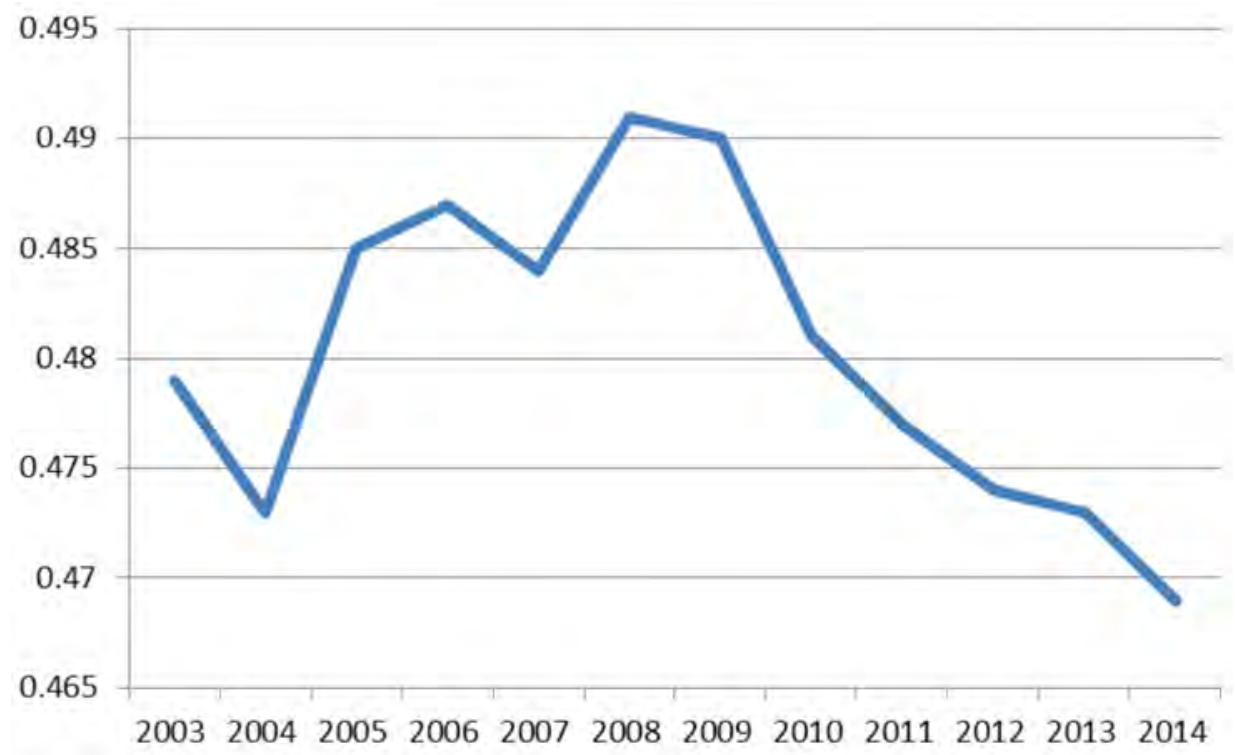

Figure 2.7 Gini coefficient of China

Source: National Bureau of Statistics. 
The investment share of output continued to rise, to a peak of nearly 50 per cent in 2011, as the fiscal and monetary expansion in response to the GFC worked its way through the economy (Figure 2.8). This is extraordinarily high compared with the experience of China in earlier times and of other economies at any time. The consumption share fell to its lowest point a year or so before that (2009 for government and 2010 for household consumption) and has slowly lifted itself from the floor since then. The fall in the investment share and rise in consumption are in the directions suggested by the new model but so far are weak to the point of imperceptibility.

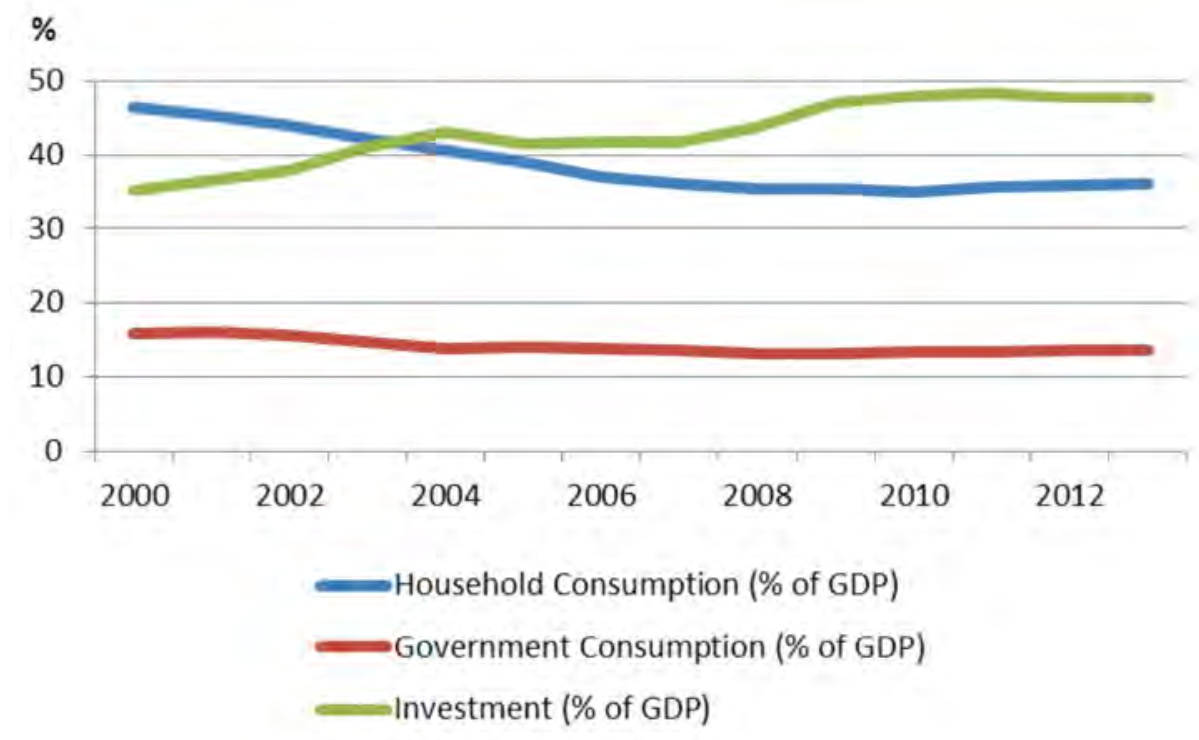

Figure 2.8 Consumption and investment share of GDP

Source: National Bureau of Statistics.

The rapid increase in domestic expenditure in the recovery from the crisis was driven much more by investment than by consumption. This was the major influence behind the rapid reduction of China's trade and current account surpluses through the post-2008 expansion (Figure 2.9).

So far, we have seen only a weak structural footprint from the new model of economic growth. This becomes clearer in Figure 2.10, which sets out The Conference Board's Beijing estimates of the contributions of growth in the labour stock, capital stock and TFP so far this century. 


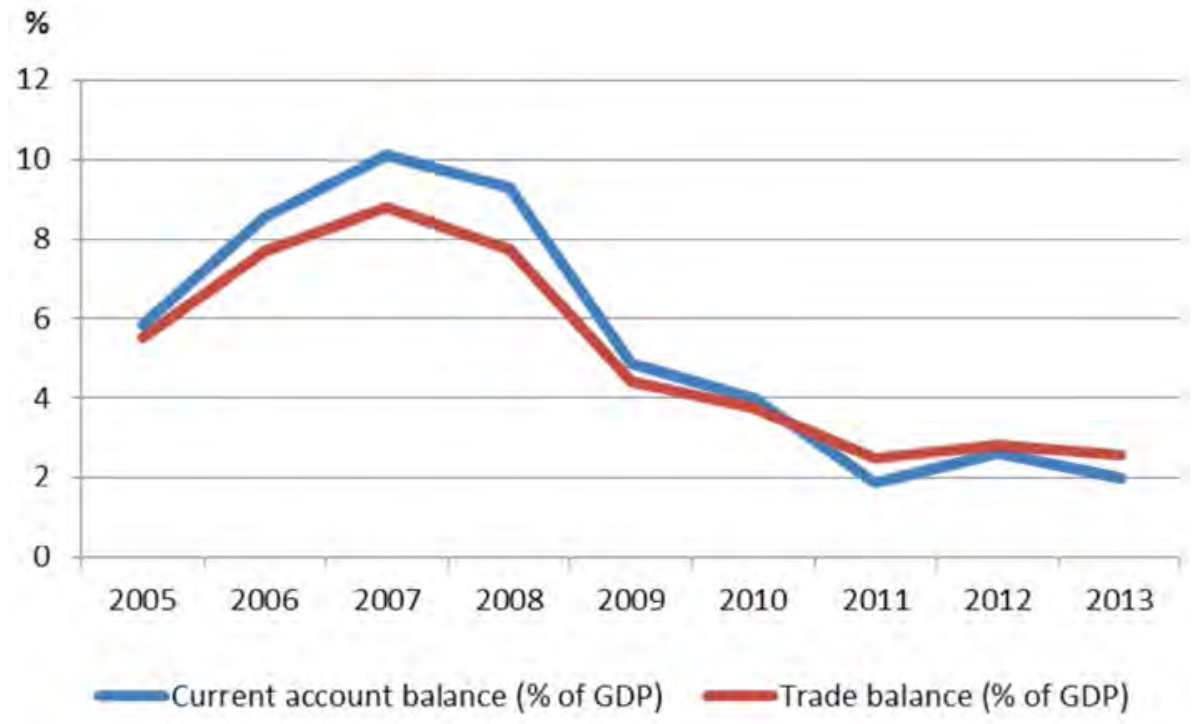

Figure 2.9 Trade balance and current account balance

Source: World Bank (various years).

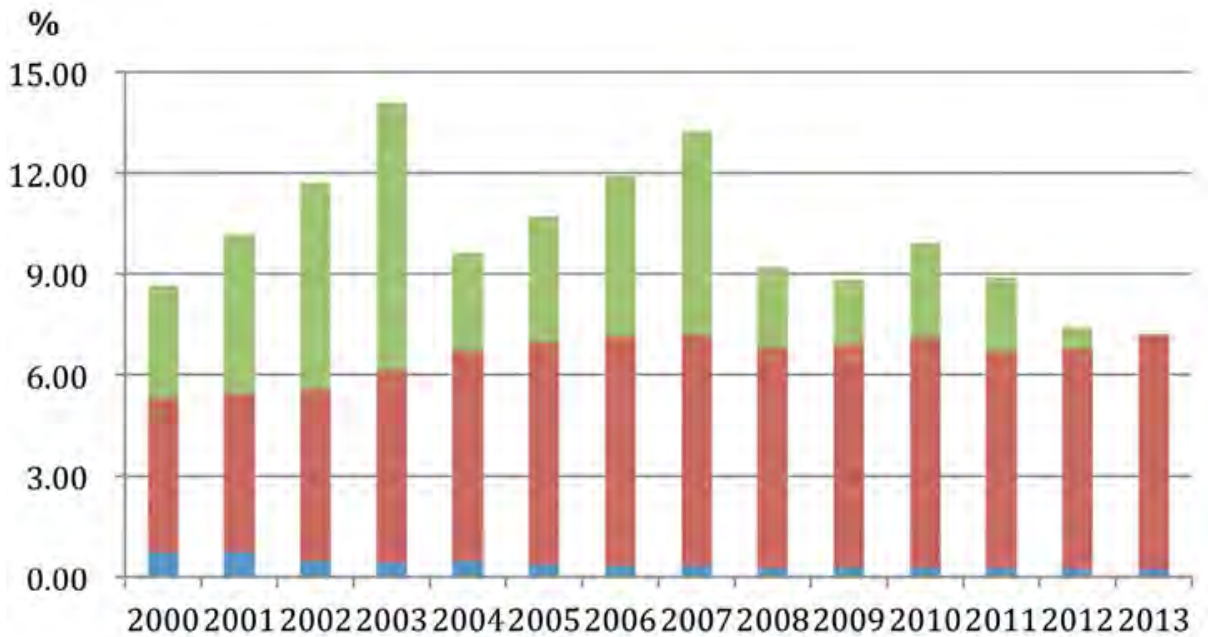

w Labour growth $=$ Capital growth $=$ TFP growth

Figure 2.10 Contributions of components of GDP growth

Notes: All growth rates are calculated as the difference in the log of the levels of each variable. GDP is measured in constant 2012 US dollars. It is updated from 2005 Elteto-Köves-Szulc (EKS) procedure purchasing power parity (PPP) with GDP deflator changes. These 2005 EKS PPPs are from Penn World, which are benchmarked on 2005 PPPs from the International Comparisons Project (ICP) at the World Bank (2005).

Source: The Conference Board (2014). 
The labour supply contribution to growth was small but positive early in the century and has since shrunk to negligible levels. That it remains slightly positive in the face of a declining population in the age cohorts that are conventionally considered to be the years of employment reflects some increase in labour force participation rates.

The growth in the capital stock has been the major contributor to growth in output through this century so far, except in 2003. It reached a high plateau of about 7 percentage points' contribution in 2006 and has remained there ever since.

While quantitatively less important than the capital contribution to growth in all but one year, the increase in TFP has made contributions to growth that are exceptionally large by the standards of other countries. Or, more accurately, it has made exceptionally large contributions until recently. The contribution fell markedly after the GFC in 2008 to almost negligibly low levels in 2012, and disappeared in 2013. There has been no sign of a decisive lift since then.

So, economic development since 2011 has been characterised by greater reliance on increases in the capital stock than at any time in the reform period from 1978.

This is such a striking and important piece of information that it is worth being cautious about its use. The April 2015 World economic outlook of the International Monetary Fund (IMF 2015) examines on a global scale the powerful tendency for TFP growth to proceed at historically low rates in many countries and regions in the twenty-first century so far, and especially in the aftermath of the GFC (Figure 2.11). It calculates 'growth potential' for many countries and sets of countries, and analyses the respective contributions to that growth potential in the labour and capital stocks and TFP. It therefore undertakes a different but similar exercise to that of The Conference Board for China. 


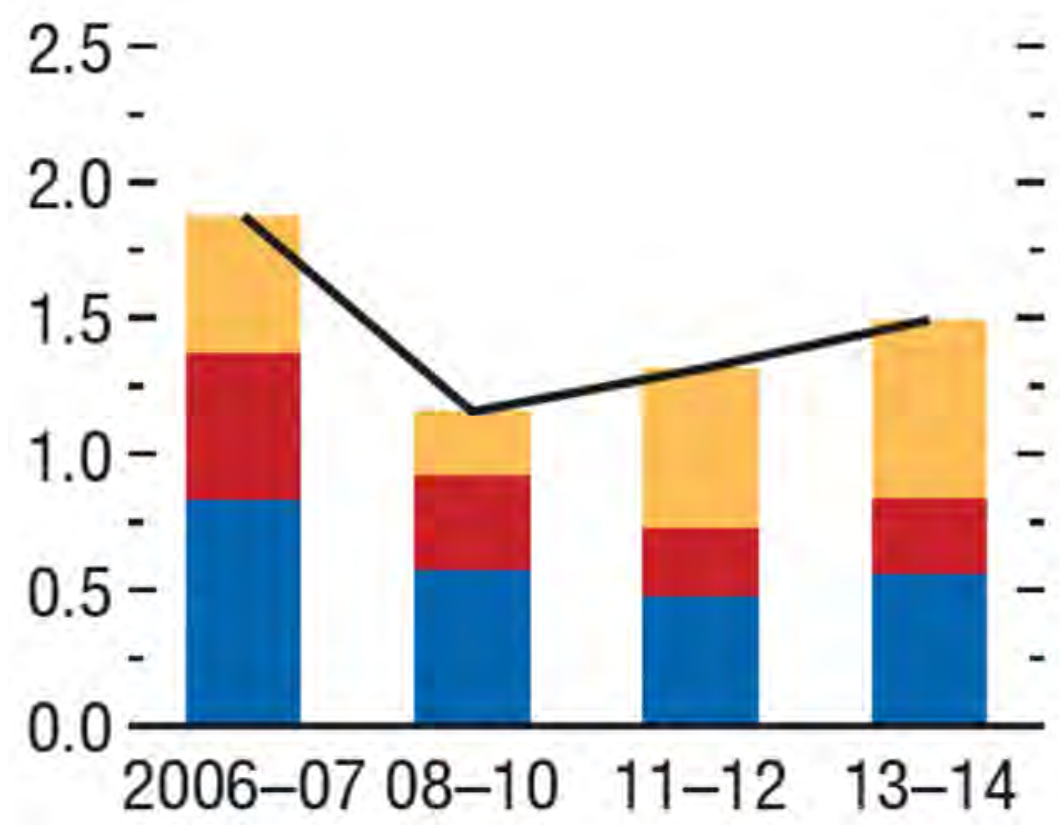

- Potential output growth Capital growth

$=$ Potential employment growth $=$ Total factor productivity growth

Figure 2.11 Contributions of components of potential output growth, 2006-14: Developed countries (per cent)

Source: IMF (2015).

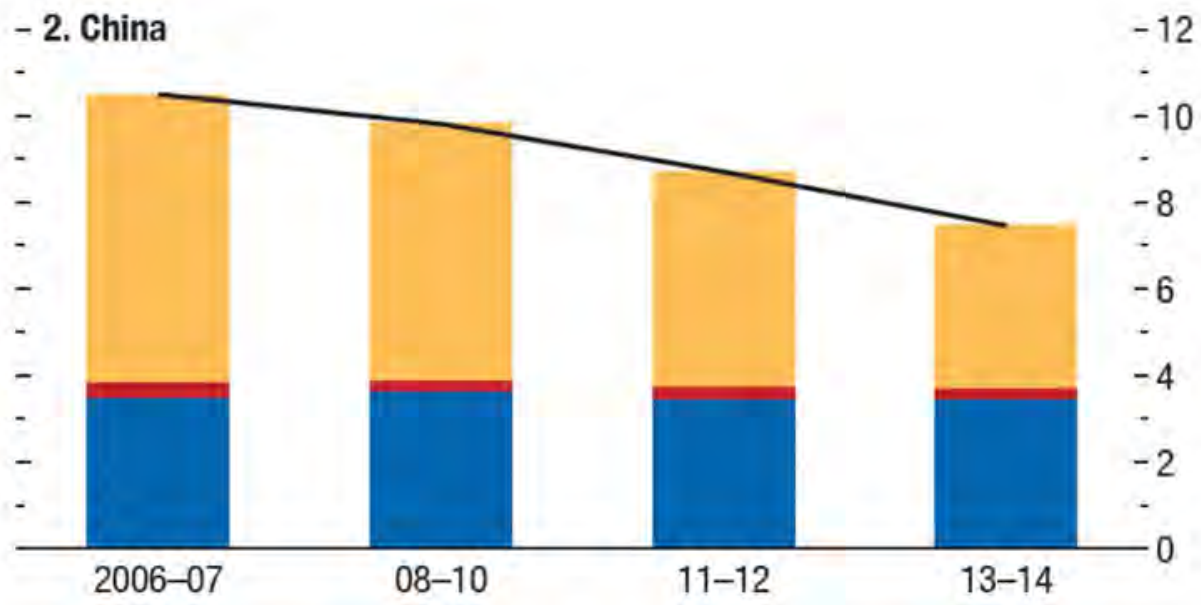

Figure 2.12 Contributions of components of potential output growth, 2006-14: China (per cent)

Source: IMF (2015). 


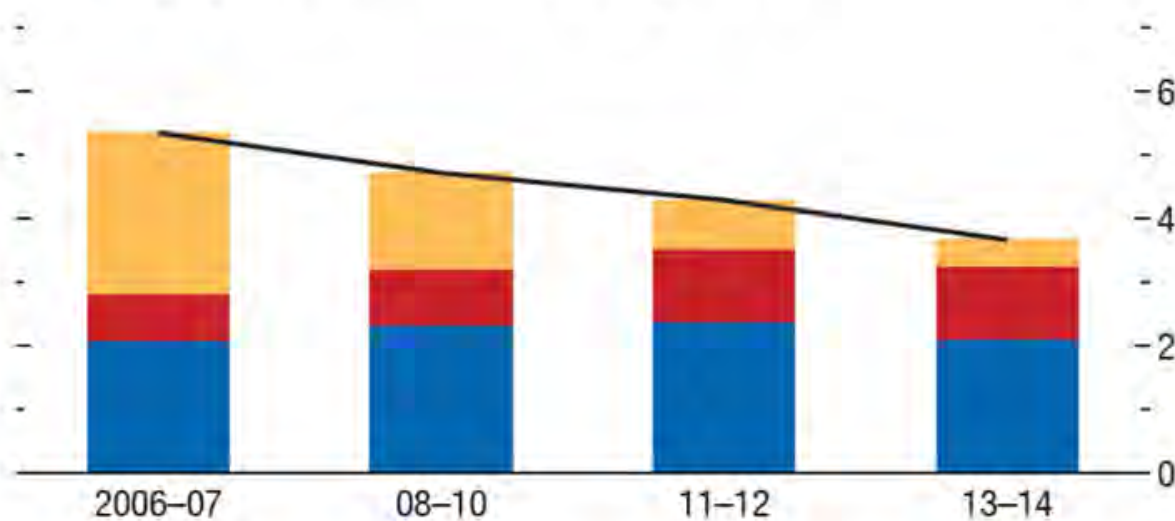

Figure 2.13 Contributions of components of potential output growth, 2006-14: Other emerging market economies (per cent)

Source: IMF (2015).

The IMF's conclusions for China are set out in Figure 2.12. They are similar to The Conference Board's results in two respects and different in two. Like The Conference Board, the IMF attributes to capital a large and steady contribution to growth potential. Like The Conference Board, it attributes a large contribution to TFP growth early in the century, and sees that contribution declining sharply during and since the GFC. However, the IMF sees TFP continuing to make a substantial if falling contribution to growth of factor productivity. And the IMF sees the capital stock continuing to make the main contribution to growth potential, but not an overwhelming one.

Part of the difference between the IMF and The Conference Board calculations derives from one looking at potential growth and the other at actual growth. If actual growth falls below potential growth, the difference will come out in the calculations as a smaller contribution from productivity growth in the former but not in the latter. In addition, there are large measurement challenges in the calculation of growth in the capital stock and therefore in calculating TFP as a residual. Differences in assumptions about rates of depreciation of the capital stock can lead to large differences in measurement of the capital stock and inversely in large differences in productivity.

We should not concern ourselves with details in the calculations. It is more useful to focus on the main general conclusions. The proportionate contribution of increase in the capital stock to growth was expected to decline over time within the new model of growth. To date, there is little sign of it having done so. 
In a scenario of smooth adjustment to China's new model of growth, steady or rising contributions from increased productivity could have offset a decline in the capital contribution. Here the evidence points to the reverse: since the GFC in 2008, productivity growth has declined markedly and economic growth is now more reliant than ever on growth in the capital stock.

We cannot avoid the conclusion that China so far has made little progress towards the macroeconomic structural changes that are necessary for success. Most of the structural change required within the new model of growth lies ahead.

The recent IMF report provides some global perspective on the recent decline in total productivity growth in China. The productivity growth decline since the GFC is also significant in the developed countries (Figure 2.12; but the decline is larger when we go back to earlier years in the current century) and other 'emerging market' economies (Figure 2.13)-larger than it is in China. This adds another note of caution about the outlook for economic growth in China. Productivity growth everywhere faces stronger headwinds in the early twenty-first century, and especially since the GFC. Growth strategies that rely on return to rates of productivity growth of earlier years could turn out to be impractical. China may have to make the structural changes required for the new model of development with lower overall rates of growth than would once have been expected and that would be helpful to smooth adjustment.

\section{Effects on the global resource sector so far}

The period in which China's growth dominated world demand for energy and metals and lifted global commodities prices to unprecedented levels has come to an end. The end of the era is most decisive for commodities for which production or use has large negative effects on local and global environmental amenity.

The end of the era is illustrated in Figures 2.1 (coal) and 2.2 (steel). China accounted for most of the global increase in demand for coal and steel from early in the century and more than the whole from the GFC of 2008 until 2011. By 2011, China accounted for close to half of global use of each of these commodities. Chinese demand growth for both commodities decelerated sharply in 2012 and 2013, and became negative in 2014. This caused growth in global demand for both commodities to turn negative in 2014.

The reduction of the local and global environmental impact of Chinese economic growth has been assisted by the structural changes associated with the new model of growth. The greater immediate effects, however, have come from the focus on environmental priorities in the new model of growth, and from 
transitional adjustment challenges left over from the old growth model. The main contributions from the new model of growth lie ahead, as the diminution of the investment share of expenditure gathers pace.

Many elements of Chinese policy aimed at directly changing the relationship between economic growth and pressure on the natural environment have been introduced since 2011. Many policy interventions have had multiple objectives: to reduce Chinese dependence on potentially unreliable external sources of resource supply; to moderate the huge deterioration in Chinese terms of trade between 2003 and 2011; to reduce and then reverse the deterioration of local air and water quality and so to diminish detrimental impacts on health and longevity; to reduce greenhouse gas emissions and therefore to contribute to the global effort to mitigate climate change; and, in a world in which 'green' outcomes are going to be increasingly important in future, to establish China as a competitive supplier of the capital goods and services that will become important in the emerging global economy.

All of these causal influences have been at work for coal and several of them for steel.

The moderation in growth and then decline in demand for coal began with commitments to reduce the intensity of economic activity from 2006. This goal was strengthened as a commitment to reduce energy intensity of economic activity by an average of 4 per cent per annum in the Twelfth Five-Year Plan. The energy intensity of economic output fell at an increasing rate in each year from 2011, reaching nearly 5 percentage points in 2014. Chinese developments within the old growth model used energy with unusual profligacy. The improvements in energy efficiency since the GFC are part of a global tendency but go well beyond developments elsewhere because they are correcting earlier excesses. The reduction in energy intensity in China in recent years has proceeded more rapidly than in any other economy.

The developments in the electricity sector are particularly important. Electricity demand grew more rapidly than economic output through the first decade of the century. Growth in economic activity has run ahead of demand for electricity since then. In 2014, when economic output increased by 7.4 per cent, demand for electricity grew by only 3.8 per cent. The whole of the diminished demand growth plus several percentage points of total electricity supply came from zeroemissions sources: in diminishing quantitative order, hydro-electricity, wind, nuclear and solar (Table 2.1). Growth in solar electricity supply has been most rapid from a base near zero four years ago. The absolute contribution of solar to the increase in electricity supply was similar to wind and nuclear in 2014, and is set to exceed them in the years immediately ahead. 
Table 2.1 Electricity generation by source, 2010-14

\begin{tabular}{|c|c|c|c|c|c|c|}
\hline \multicolumn{7}{|c|}{ Quantity (million Mwh) } \\
\hline Year & Total & Thermal & Hydro & Nuclear & Wind & Solar \\
\hline 2010 & 4,228 & 3,416 & 687 & 75 & 49 & 0 \\
\hline 2011 & 4,731 & 3,900 & 668 & 87 & 74 & 1 \\
\hline 2012 & 4,986 & 3,925 & 856 & 98 & 103 & 4 \\
\hline 2013 & 5,372 & 4,222 & 892 & 112 & 138 & 9 \\
\hline 2014 & 5,550 & 4,205 & 1,070 & 126 & 156 & 23 \\
\hline \multicolumn{7}{|c|}{ Rise over previous year (\%) } \\
\hline Year & Total & Thermal & Hydro & Nuclear & Wind & Solar \\
\hline 2010 & 14.9 & 13.4 & 20.1 & 6.7 & 78.9 & 74 \\
\hline 2011 & 11.9 & 14.2 & -2.7 & 16.7 & 49.9 & 459 \\
\hline 2012 & 5.4 & 0.6 & 28.1 & 12.7 & 39.1 & 412 \\
\hline 2013 & 7.7 & 7.6 & 4.2 & 14.3 & 34 & 125 \\
\hline 2014 & 3.3 & -0.4 & 20 & 12.5 & 13 & 156 \\
\hline
\end{tabular}

Source: National Bureau of Statistics of China and China's National Energy Administration.

Thermal electricity output fell in 2014. Within the diminishing total, the share of zero-emission (biomass) and low-emission (gas) sources of thermal electricity rose rapidly from a low base. Thermal coal consumption fell by 2.9 per cent.

The early months of 2015 have seen an accelerated decline in thermal power generation from coal. Thermal coal use was 10 per cent lower in the March quarter than in the corresponding period of the previous year. Chinese imports of coal, which became the largest in the world through the period of strong, energy-intensive growth, fell by 42 per cent in the first quarter of 2015 compared with the previous year.

Many and varied policy interventions have been applied to moderate demand for electricity and to shift supply away from use of coal. The most powerful early interventions were regulatory: the forced closure or transformation of facilities that failed to meet increasingly high emissions standards. Propaganda played an important role in changing behaviour. Many subsidies for production and use of low-emission technologies were influential. Increased taxes and reduced subsidies on fossil fuels had large effects.

For the future, the government has heralded a shift towards greater reliance on market-based mechanisms. It has announced that the pilot emissions trading schemes in five cities and two provinces will be merged into a national emissions trading scheme from 2016. Regulatory interventions, taxes and subsidies are likely to remain important in maintaining momentum in the transformation of the local and global environmental impact of the Chinese energy sector. 
Steel demand also decelerated markedly from 2012. It fell absolutely in 2014, and again in the first quarter of 2015. Production has also fallen but by smaller amounts as part of the Chinese supply has been exported with losses by the steelmaking enterprises.

For steel, the long-term structural effects of the new model of growth are large, but have been eclipsed for the time being by more immediate challenges. Steel demand has been affected powerfully by the cutback in infrastructure and real estate investment in response to oversupply and the associated fragility of financial institutions. The focus on environmental amenity, especially near the great urban regions of coastal China-Beijing-Hebei-Tianjin, ShanghaiJiangsu-Zhejiang and the Pearl River Delta-has led to early closure of many steelmaking facilities. The effects of reduced investment shares of output lie ahead.

The deceleration of growth in Chinese steel demand after 2011, and the absolute decline in 2014 and early 2015, has been the main factor behind the absolute fall in global steel demand since 2012 (Figure 2.2). Chinese steel demand can be expected to continue to fall with the investment share of expenditure within the new model of growth. Production of new steel and demand for primary steelmaking raw materials can be expected to fall more rapidly than steel demand, as the proportion of scrap available as an input into steel production rises towards the normal levels of the developed countries with the maturation of Chinese development.

Global supply of energy and metals was slow to recognise and then respond to the acceleration of Chinese demand growth from the beginning of the century. That contributed to the extraordinary increase in global prices for almost all metals and energy. Global supply eventually responded to higher prices and prospects for increased demand; but the largest expansion in supply, from 2011, coincided with the deceleration of and then decline in Chinese demand.

The global price profiles for coal, oil and copper in Figures 2.3, 2.4 and 2.5 are similar to those for nickel, iron ore, gas and most other commodities: sharp increases from 2003 to the eve of the GFC in 2008; large falls in late 2008 and 2009; a rise to near or beyond pre-GFC heights in 2010 and 2011; and declines from 2011 with the coincidence of deceleration of demand growth in China and increased global supply. The global resources industries are left with a problem of oversupply and the challenge of adjustment of historic dimension.

China, like other resource-importing countries, has benefited from oversupply of metals and energy through a large improvement in its terms of trade. Continued gains from this source will ease the costs of adjustment to the new model of 
growth. Low and declining prices can be expected to continue until enough old or new supply capacity has been removed to establish a global balance between supply and demand at a lower level of Chinese demand.

The improvement of Chinese terms of trade since 2011 has already been of large dimension and has further to go. It is the other side of the coin to the large fall in the terms of trade, adjustment challenges and setbacks to economic growth in resource-exporting countries. Australia has been experiencing slow growth in incomes and employment since Chinese demand and global prices for metals and energy began to fall in 2011, and will be grappling with the consequences of the end of the resources boom for many years (Garnaut 2013). Indonesian policy dampened the supply response to the higher metals and energy prices for all commodities except coal, but the supply response in coal was strong enough to leave the country with a major adjustment problem in the aftermath of the boom (Garnaut forthcoming 2015). Johnston has drawn attention to the sharp deceleration of growth in West African countries with the fall in export prices for metals and energy (Johnston this volume).

China's increased prominence in the global economy in the twenty-first century has made adjustment to its new model of growth a major challenge for the rest of the world.

\section{The prospects for Chinese growth and the global resources sector}

The lower rates of growth in China since 2011 seem to reflect the effects of structural problems inherent in the old model of growth as much or more than the effects of transition to the new model of growth. While the long, upward movement in the investment share of output and the fall in the consumption share have been brought to an end, the reversal of the old trends has barely begun. While the upward adjustment in domestic expenditure relative to income has secured the necessary moderation of the immense pre-crisis trade and current account surpluses, it did this through increasing investment more than consumption. There has been considerable moderation in investment in industries excessively favoured by the old model of growth - so far without significant moderation of overall rates of investment. And the large decline in productivity growth is reducing the prospects for the eventual decline in the capital contribution to growth being substantially offset from this source, at least in the early stages of transition. 
China has made a start on the transition to its new model of growth. It has made a big start in reduction of the environmental impact of economic growth; but all elements of transition have a long way to go.

\section{References}

BP (2015), Energy charting tool, London: BP. Available from: www.bp.com/en/ global/corporate/about-bp/energy-economics/energy-charting-tool.html.

Cai, F. (2010), Demographic transition, demographic dividend and Lewis turning point in China, China Economic Journal, 3(2): 107-19.

Chai, J. (2015), Under the dome, [Documentary]. Available from: www.youtube. com/watch?v=MhIZ50HKIp0. Retrieved May 2015.

Chen, Y.Y., Ebenstein, A., Greenstone, M. and Li, H.B. (2013), Evidence on the impact of sustained exposure to air pollution on life expectancy from China's Huai River policy, Proceedings of National Academy of Sciences of the US, 8 July, Beijing.

Datastream, a standing online commercial data service provider.

EIA U.S. Energy Information Administration providing Official Energy Statistics from the U.S. Government

Garnaut, R. (2010), Macro-economic implications of the turning point, China Economic Journal, 3(2): 181-90.

Garnaut, R. (2013), Dog days: Australia after the boom, Melbourne: Black Inc.

Garnaut, R. (forthcoming 2015), Indonesia's resources boom in international perspective: Policy dilemmas and options for continued strong growth (the Ninth Sadli Lecture), Bulletin of Indonesian Economic Studies.

Garnaut, R. and Song, L.G. (eds) (2006), The turning point in China's economic development, Canberra: ANU E Press.

Garnaut, R., Cai, F. and Song, L.G. (eds) (2013a), China: A new model for growth and development, Canberra: ANU E Press.

Garnaut, R., Cai, F. and Song, L.G. (2013b), China's new strategy for long-term growth and development: Imperatives and implications, in Garnaut, R., Cai, F. and Song, L.G. (eds), China: A new model for growth and development, Canberra: ANU E Press, pp. 1-16. 
Huang, Y. and Cai, F. (eds) (2013), Debating the Lewis turning point in China, London: Routledge.

Huang, Y. and Jiang, T. (2010), What does the Lewis turning point mean for China? A computable general equilibrium analysis, China Economic Journal, 3(2): 191-207.

Huang, Y., Fang, F., Xu, P. and Xin, G. (2013), The new normal of Chinese development, in Garnaut, R., Cai, F. and Song, L.G. (eds), China: A new model for growth and development, Canberra: ANU E Press, pp. 35-54.

Index Mundi (2014), Coal, Australian thermal coal monthly price: US dollars per metric ton, Index Mundi. Available from: www.indexmundi.com/ commodities/?commodity=coal-australian.

International Monetary Fund (IMF) (2015), World economic outlook: Uneven growth-Short- and long-term factors April 2015, Washington, DC: IMF. Available from: www.imf.org/external/pubs/ft/weo/2015/01/. Retrieved May 2015.

IMF-IFS International Financial Statistics of the IMF, an international organization publishing a range of time series data on IMF lending, exchange rates and other economic and financial indicators.

McLeod, R.H. and Garnaut, R. (eds) (1998), East Asia in crisis: From being a miracle to needing one?, London and New York: Routledge.

National Bureau of Statistics of China, a government agency directly under the State Council, in charge of statistics and economic accounting in China.

National Energy Administration of China, responsible for formulating and implementing energy development plans and industrial policies, and also provides related data series.

Penn World Table from Center for International Comparisons at the University of Pennsylvania, provides purchasing power parity and national income accounts converted to international prices for 189 countries/territories for some or all of the years 1950-2010.

Perkins, D.H. (2013), New institutions for a new development model, in Garnaut, R., Cai, F. and Song, L.G. (eds), China: A new model for growth and development, Canberra: ANU E Press, pp. 17-34.

The Conference Board (2014), Total economy database, January, New York: The Conference Board. Available from: www.conference-board.org/data/ economydatabase/. 
China's Domestic Transformation in a Global Context

Wong, C. (2015), Can Xi Jinping's reforms be implemented? Let's look at China's fiscal architecture, Centre for Contemporary Chinese Studies academic seminar, 5 March 2015, University of Melbourne.

World Bank (various years), World development indicators, Washington, DC: The World Bank. Available from: data.worldbank.org/data-catalog/worlddevelopment-indicators.

World Steel Association (2015), Crude steel production 2014-2015, Brussels: World Steel Association. Available from: www.worldsteel.org/statistics/ crude-steel-production.html.

Yu, Y. (2009), China's policy responses to the global financial crisis, The 2009 Snape Lecture, Australian Productivity Commission, Melbourne. Available from: www.pc.gov.au/news-media/snape-lectures/yongding. Retrieved May 2015. 
This text is taken from China's Domestic Transformation in a Global Context, edited by Ligang Song, Ross Garnaut, Cai Fang \& Lauren Johnston, published 2015 by ANU Press, The Australian National University, Canberra, Australia. 